\title{
The Stuff of Translation and Independent Female Scientific Authorship: the Case of Taxidermy..., anon. (1820)
}

\author{
Mary Orr
}

The anonymous Taxidermy: or the Art of Collecting, Preparing and Mounting Objects of Natural History. For the Use of Museums and Travellers was first published by Longman in 1820. Due to its immediate success as an authority, it went through four revised reprints in 1821, 1823, 1829 and 1835 (still anonymously), before a much expanded sixth edition appeared in 1843. This included an "advertisement" for the first time, unequivocally to establish the author as Mrs R. Lee (1791-1856), and the work as the frequently plagiarised source of "all modern treatises on Taxidermy [...] as if an anonymous author were a fairer object for piracy than one whose name stands on the title page" (Lee, "Advertisement" iv). Her name is, in fact, equally absent from the title pages of the some dozen books (see: Appendix 1 below) she co-authored and cotranslated anonymously with her first husband, T. Edward Bowdich (1791-1824), the explorer of Ashanti (see: Driver, "Thomas Edward Bowdich"). Taxidermy stands out among them all in terms of its sole authorship thanks to the retrospective evidence of its 1843 "advertisement":

the task devolved to me alone, and for the better execution of it, I not only read the best writings on the subject, and consulted those most skilled in the Art, but verified all my instructions in the laboratories of the Museum in Paris. Several of the following pages are mere translations from printed memoirs, chiefly that of M. Dufresne. Others are noted down from explanations given viva voce; but these were so mingled with original matter that it is impossible to separate them from each other. (Lee iii, emphasis added)

If Connor notes that Sara [sic] Bowdich in 1820 is the first to use the "up-register "taxidermy" (rather than the word "stuffing"), this article makes more specific and wide-reaching claims. It demonstrates that Sarah Bowdich's Taxidermy was the first major work on the subject in English, as well as in other European languages, to be authored by a woman. By so doing, the article also renegotiates, through Taxidermy as a case-study, why even the best approaches of history and sociology of science arrive with difficulty at such findings, and why other critical approaches are also necessary to locate similar works in science significantly reshaping their fields, especially when published anonymously, by women.

Historical and sociological research very convincingly explains the presence (or absence) of women in science in the early-to-mid nineteenth century through the many exclusions and obstacles that they faced. As McEwan's Gender, Geography and Empire, Driver's Geography Militant: Cultures of Exploration and Empire Kohlstedt and Opitz's "Re-imag(in)ing Women in Science" and Livingstone and Withers" Geographies of Nineteenth-Century Science variously endorse, women in the period had little or no access to a scientific education and training in museum collections, to learned societies and their outlets for publication, or to expert knowledge gathering 
overseas. In consequence they negotiated various secondary roles - as translators, illustrators and popularisers of scientific works by men related to them by blood or marriage - as strategic back-door routes for their own contributions to natural science and geology (see: Abir-Am and Outram; Burek and Higgs). These explanations are problematic, however, when it comes to understanding why and how the relatively few women in science - such as Sarah Bowdich (Lee) - emerge nevertheless in primary capacities in this period. At best they are exceptions to the rule, anomalies, minority and marginal figures: at worst they are monstrous cases, as Clémence Royer (18301902) famously exemplifies. She is now known as the first (mis)translator of Darwin's On the Origin of Species into French in 1861, (mis)appropriating his work somewhere on a scale between opportunist rewriting (see: Fraisse; Harvey) and wilful misrepresentation (see: Miles; Brisset).

The successful (including notorious) exchange, circulation and advancement of new ideas - religious, political, artistic and scientific - have, however, always depended on multi-lingual, and intra-lingual, re-articulation in many forms and genres. For example, translations, abridgements, popularisations and fictionalisations variously ensure the onward dissemination of human understanding for a range of new audiences. By framing women's knowledge in science within the discourses of socio-political exclusion and exception, historical and sociological research (in all periods) too frequently overlooks women's multi-lingual proficiency, and this as the vehicle allowing them direct access to primary spaces for their own independent contributions. The configuration of women's secondary roles in science as "translators" and "popularisers" assumes a similar secondary status for such activities as derivative, unmediated (mechanical) reproductions of the original in the other language. For literary studies, by contrast, especially on women's and postcolonial writing since the 1970s, the "subaltern" subject (see: Spivak) finds a voice through carefully-constructed agency in master discourses. In the nineteenth century, European women working as creative writers variously negotiated what Mary Poovey calls the "ideology of style" (The Proper Lady and the Woman Writer) to circumnavigate the socially-constructed proprieties delimiting female authority and authorship. Frequently in the period women authors had to adopt a (male) pseudonym or pen their work anonymously (see: Easley). Travel and translation studies which foreground gender (by, for example, Pratt; Mills; Simon; and Bassnett), have uncovered many important nineteenth-century women travel writers who operated similarly. Because they additionally took on in their writing practices the genres of rugged exploration and expert observation, their work as "translators" and "popularisers" of science and travel accounts widened the cultural and intercultural parameters for contribution to factual writing (geography, natural science, geology), including by women, in both national and transnational heritages. As Martin ("Performing Scientific Knowledge Transfer") in this special issue, and Martin and Pickford further explore in their edited volume Travel Narratives in Translation, 17501830, women translators of scientific travel texts (by men in other languages) of the period also made independent primary scientific contributions, for example through their diligent recasting and correction of erroneous information, or insertion of explanatory footnotes not in the original.

The approaches of history and sociology of science (including scientific biography) are thus essential to our reading of Taxidermy as a scientific text and wider case study, but are inflected and extended by harnessing the insights of comparative literary, travel and translation studies. Moreover by framing this British woman writer of science transnationally through her engagement with other languages, our reading brings more fully into the spotlight Sarah Bowdich's proactive contribution in 
Taxidermy to various genres of science writing normally classified as "rugged." Through close literary-critical reading of Taxidermy in the multiple socio-historical and biographical contexts that produced it, this article uncovers for the first time that this work is in fact no seamless "translation" or reproduction of one original text, but realigns two. Taxidermy's "intertextuality" - namely its imitation, adaptation and translation (Orr, Intertextuality) of the several factual genres it sets authoritatively in display - are therefore of immense interest to history of science. It is through literarycritical insights, however, that explanations can be given for the specific agendas the anonymous Sarah Bowdich (Lee) promoted in her recrafting of this work.

Taxidermy has elicited only passing critical attention in the history and literature of science. The fullest discussion to date within the history of science of its field is Morris's History of Taxidermy (336-37). By quoting elements from the 1843 "advertisement" (see above), Morris remains curiously adamant that Edward Bowdich authored this "translation," and penned the drawings (despite their clear signature as "S. Bowdich del"). While Beaver is principally to be thanked for bringing "Mrs R. Lee" to critical attention in the history of science through his meticulous scientific biography of her life and works, Taxidermy is not singled out. This was the object of women's writing (and women's science writing) specialist, Barbara Gates who, in first anthologising Taxidermy, drew attention to the importance of its author and her science for studies of women's scientific writing. My own work in a similar vein ("Pursuing Proper Protocol: Sarah Bowdich's Purview of the Sciences of Exploration"; "Women Peers in the Scientific Realm") in nineteenth-century French literary science has focused on the importance and significance of Sarah's rather unusual training for the time (in 1819-22) under Georges Cuvier and others at the Jardin des Plantes in Paris (when the Bowdichs were preparing their independent, jointly conducted, voyage of scientific discovery to Sierra Leone). After Edward's death in The Gambia in 1824, further evidence for Sarah's independent collaborations with Cuvier (including contributions to his definitive The Natural History of Fish [Histoire naturelle des poissons]) derives from Sarah's additional information about preservation of fish in the 1843 edition of Taxidermy (Orr, "Fish with a Different Angle"). In fact its "advertisement" (cited above) is a model of contextual succinctness regarding the activity and importance of taxidermy at the Jardin des Plantes in 1820 for (French) history of science, including the unusual presence within it of a (British) woman receiving "instructions" in the "laboratories" and "consult[ing] those most skilled in the Art."

For historians of French science and education such as Bret, Blanckaert et al and Williams, Napoleon's First Empire secures France's international standing and standard for science collections and endeavour by also instigating training at secondary and tertiary levels in mathematical and scientific subjects. Women in France were automatically excluded from all these activities, because they could not be soldiers, scientific specialists or science teachers. However, because Napoleon instituted French to replace Latin as the lingua franca of post-Revolutionary science (and French science education), historians of science of the period overlook the multiple impacts of this medium for the constituency of both French and international science communities in the remainder of the nineteenth century. Frenchmen from modest backgrounds were no longer barred from becoming scientific assistants ["aides naturalistes"] at the Jardin des Plantes and other French institutions. After the Napoleonic Wars these could also reopen their doors to overseas experts fluent in French and/or who were otherwise barred by class, creed, sex or race from their scientific institutions "at home." 
Indicative and illustrative of exactly this latter situation was the arrival in 1819, and activities over four years, of Edward and Sarah Bowdich at the Jardin des Plantes. Their subsequent contributions to French and international science also exemplify the far-reaching importance of multilingual proficiency alongside specialist scientific expertise. Because their earlier joint mission to Ashanti attracted no further financial backing from The African Society, the Bowdichs combined their efforts in Paris to prepare their (second) voyage of scientific exploration to West Africa. Their intensive accumulation of the latest French scientific knowledge was further channelled into their publications for informed English readerships, which provided the means to fund their independent journey. The list (see: Appendix 1) comprises key works about recent (French scientific) travel to West Africa, and the latest advances by Chairs in natural science at the Jardin des Plantes. Cuvier's new classification system for the (global) animal kingdom - his Règne animal was published in 1817 - directly informed the ornithology he was preparing when the Bowdichs arrived in Paris. Lamarck was also developing new work on molluscs and shells. The publications (in Appendix 1) highlighted in bold directly map onto these new advances.

Like the massive (re)classification project of all known species at the Paris Museum of Natural History, at the Jardin des Plantes in miniature, the very number, range (and also length) of the publications attributed to "T. Edward Bowdich" cannot be the single-handed work of one named (or anonymous) author. Sarah's second pair of expert hands in the four years of these productions is additionally visible through her signature on the many hundreds of accompanying figures in the highlighed works in Appendix 1, taken from specimens in the Museum's galleries and collections. Moreover these titles were not English translation copies of a French original, but compact singlevolume compendia of the latest available information gathered from various recent sources. The object of the Bowdich versions was therefore to reduce encyclopedic contemporary French coverage of natural history into portable single-volume reference works for future curatorial assistants ["aides naturalistes"] in Museums as well as for travellers ["voyageurs naturalistes"]. I will return to the bracketed French designations below. Despite their accessibility, and resemblance to textbook primers - signalled by the words "elements," "introduction," "analysis" in the hightlighed titles - they were clearly not for beginners. Their short textual descriptions are organised under the new classification systems of Cuvier and others, enhanced and cross-referenced by the foldout charts of drawings, to facilitate correct identification, description and classification practices for known and unknown species either in the field or in the laboratory. No successful scientific expedition merely recorded descriptions of new findings in notebooks. For the scientific traveller/museum collector worthy of the name, the carefully labelled found specimen was the primary evidence on which any reliable new report with drawings was based. Transmission of new observations and identifications was therefore as dependent on correct preservation and transportation of objects of natural history as on detailed records. In consequence, expert scientific collection of species from hot, damp, insect-rich climates was particularly important since these spoiled most rapidly, even before lengthy and perilous sea transport to national museums to enable their further study. Enter the arts and sciences of "taxidermy" - the 1806 coinage for "preserving" - without which no post-Revolutionary (French) scientific traveller of note or ambition could set out (following the model exploration and herbarium preservation practices of Alexander von Humboldt), and upon which museum specialists relied to verify new findings.

The methods of drying specimens (see: Péquignot) or pickling them in spirits date from before 1750 of course, but limited royal and other collections largely to 
unfleshy forms that still suffered decay and insect infestations. With the arrival from colonial outposts of new living exotica (especially colourful birds), came the necessity of their keeping - alive or dead - through building collections. The histories of natural science and museology therefore made unprecedented strides from 1770 as much through important discoveries in conservation and preservation techniques, such as the "arsenical soap" of the pharmacist (and collector of birds) Bécoeur of Metz, as through great voyages of exploration. In fact several major collectors of birds and insects "at home" - l'Abbé Denis Joseph Manesse (1743-1820), Pierre-François Nicolas (17431816), Jacques-Marie-Philippe Mouton-Fontenille de la Clotte (1769-1837), Louis Dufresne 1752-1832) in France; ${ }^{1}$ John Coakley Lettsom (1744-1815) and William Bullock (1773-1849) in Britain - all wrote important treatises (of which, more below) on how better to prepare, preserve and conserve objects of natural history for the establishment of collections of scientific importance, both private and national. Sarah Bowdich's Taxidermy of 1820 is a major missing link in their transmission precisely because of its dual linguistic, but also generic, contexts of production. Its significance has not been appreciated to date because no critic has delved into its composite, bilingual intertextuality, clearly announced in nuce in the 1843 "advertisement":

I not only read the best writings on the subject, and consulted those most skilled in the Art, but verified all my instructions in the laboratories of the Museum in Paris. Several of the following pages are mere translations from printed memoirs, chiefly that of M. Dufresne. Others are noted down from explanations given viva voce; but these were so mingled with original matter that it is impossible to separate them from each other. (Lee iii, emphasis added)

The incipit to Taxidermy (1820) is a chief example:

This treatise is written to facilitate the means of procuring and preserving skins. It will contain a careful description of the Proceedings necessary to collect and preserve all the objects of the animal kingdom.

We find the more pleasure in guiding young naturalists in their interesting labours, as our efforts, for the last fifteen years, have already been rewarded. Since the publication of the first edition, the number of persons who apply themselves to Taxidermy is singularly increased, not only in Europe, but in all parts of the world; and we have had the satisfaction of observing, that almost all the animals sent to the Museum in Paris, have been prepared according to the methods we have recommended.

Natural history can only make a rapid progress when museums are enlarged, multiplied and perfected in the art of preparing, mounting, and preserving animals. (1)

*

[Les premiers essais de ceux qui se livrent à l'étude d'histoire naturelle se portent généralement sur les objets qui frappent le plus leurs yeux. Ainsi, les animaux, et particulièrement les oiseaux, attirent l'attention de tous les voyageurs.

C'est pour leur faciliter les moyens de se procurer et de conserver ces précieuses dépouilles que nous avons écrit cet article. Il contiendra la description soignée de divers procédés employés pour recueillir et préserver 
tous les objets compris dans le règne animal. Nous trouvons d'autant plus de plaisir à guider les jeunes naturalistes dans leur intéressans travaux, que déjà les efforts que nous avons faits pour eux, il y a quinze ans, sont récompensés. Depuis la publication de la première édition de ce Dictionnaire, en 1803, le nombre de personnes qui s'occupent de taxidermie s'est singulièrement accru, non-seulement en Europe, mais dans toutes les parties du monde, et nos avons eu la satisfaction d'observer que presque tous les animaux envoyés au Muséum de Paris sont préparés d'après les procédés que nous avons indiqués.

Les sciences naturelles n'ont pu nécessairement faire du progrès rapide, qu'à mesure que les musées se sont multipliés et perfectionnés dans l'art de préparer, monter et conserver les animaux]. (Dufresne, "Taxidermie" 522-23)

By placing the English translation above Dufresne's source text, what "most strike the eyes" ["les objets qui frappent le plus leurs yeux"] are not natural objects such as birds ["les oiseaux"], but the misrepresentation, even potential plagiarism, of Sarah's Bowdich's translation through omission of Dufresne's original opening paragraph. Reference to "the first edition" in her second paragraph is confusingly not some mistake, for example that her 1820 text is in fact its second reprint of 1821. Rather, her suppression of Dufresne's qualifying "Dictionnaire, en 1803" (in the second paragraph of the French original) further confuses his efforts over fifteen years with hers. Worse still, further cross-checks of the English Taxidermy paragraph by paragraph against Dufresne's second revised entry for "Taxidermie" of 1816-19 confirms Sarah's is an almost exact copy of this version, with only further minor suppressions of detail such as this one. The many references within Dufresne's article to other authorities - such as Manesse and Nicolas - are therefore his, not Sarah's, reading of "the best writings on the subject" as she claims in her "advertisement" above. As Morris (A History of Taxidermy 336-37) correctly observes, the Bowdich Taxidermy is one of two important English translations of Dufresne's work, both published in 1820: its rival The Taxidermist's Manual or the Art of Collecting, Preparing and Preserving Objects of Natural History by Captain Thomas Brown enjoyed even more reprints, particularly in North America. Brown had gone to Paris specifically to purchase Dufresne's extensive stuffed bird collection for the University of Edinburgh (Sweet, "The Collection of Louis Dufresne"), and hence had as direct access to this expert "manual" and work on taxidermy as Sarah Bowdich. At best, this British woman translator living in Paris at the time was an opportunist money-spinner, rather coy with the truth concerning the direct provenance of her work, even when calling attention to Dufresne in the 1843 "advertisement."

The truth is, however, rather different when viewed from informed comparative literary-cultural and intertextual investigations of source and non-source texts in both Brown's The Taxidermist's Manual and the 1820 Taxidermy, including its reprints. Brown much more concertedly disguises and erases Dufresne as his guiding reference: he is not among the "authorities," for example Waterton and Audaubon, named in Brown's "Introduction." Cross-checks with Dufresne's "Taxidermie" (1816-19) also rapidly reveal that Brown everywhere rearranged its structure and order, so that translations of directly lifted paragraphs from different sections are restitched into Brown's own reconstruction as if of his piece. Brown includes various plates - there are none in Dufresne - again without acknowledgement of his sources. In short, Brown's recomposition as self-fashioning - mirroring the artificer keyword of his title - is as the entrepreneur closing on his future roles as "conservator of the Manchester Museum of Natural History" (as subtitle pages of subsequent editions of The 
Taxidermist's Manual confirm). Its multiple reprint success over a fifty-year period maps directly onto the rise of taxidermy businesses meeting the demands of bourgeois leisure pursuits (for both sexes), and in all zones of the Anglosphere, as Marcinkus and Coote underscore.

By contrast, Sarah Bowdich's Taxidermy: on the Art of Collecting, Preparing and Mounting Objects of Natural History is guided by the word "collecting" of her subtitle, covering the issues of "preparing" and "mounting." Dufresne's "Taxidermie," which she is collecting in translation as summa of the most recent (1819) and reliable expertise on the subject by the chief taxidermist ["préparateur"] for the Paris Museum, is but the preface in her work - it is almost twice as long again - very specifically written for "Museums and Travellers." Her omissions in the 1820 Taxidermy from Dufresne, and additional minor cuts to it in her subsequent reprints are subtle adaptations pointing to her wider remits for the volume as a whole. For example in her second (1821) and all further editions, the opening two paragraphs of the 1820 text (with their ambiguities about Dufresne's second edition) have disappeared. Strategically, Taxidermy then opens with: "Natural history can only make a rapid progress when museums are enlarged, multiplied and perfected in the art of preparing, mounting, and preserving animals." But these minor adaptations also include her independently authored, and clearly flagged, supplements very specifically referring to Dufresne's work - as an authority text; as the chief practitioner-teacher she consulted - both in the 1820 version and more unmistakably in further editions, because she signs this material " $T$ " (translator). An example is a note to the fifth edition (93) adding new material to Dufresne's original work.

Aside from following Dufresne's authority text in order and coverage, Sarah Bowdich's "translation" further provides verifications and clarifications of his expert practices as a vehicle also for her own authoritative extensions of them (and ahead of undertaking such work independently in the field in Sierra Leone). One example makes these points:

It is necessary to use the oil of turpentine for the exterior of large quadrupeds, and fish, first because the metallic soap cannot penetrate, and secondly, because prudence does not allow us to employ it, on the surface of any animal, not even on the parts free from hair.*

* M. Dufresne means the exterior surface only, which is so much handled in the shifting as to make it too dangerous to anoint it with this soap; and I observe, that the Artists in the Zoology Laboratory at Paris, carefully bend or turn down the points of the various wires, after they have inserted them (as they easily straighten them again with the fingers, if requisite), lest by pricking their fingers, the arsenic might do them serious injury. M. Valenciennes, however, assures me, that it is indispensably necessary for the traveller to anoint the naked parts of the legs of birds killed in hot climates. (Taxidermy 14, underlining in the original)

As a "traveller" in the preparation herself in 1820 (and in the 1821 and 1823 re-editions of Taxidermy) Sarah's clarification of Dufresne by her underlining in this note directly connects to her own authoritative "I observe." Not only is she retransmitting Dufresne's authority. Through her first-person experience of his work as her foremost teacher, she also further qualifies and extends his expert instructions with her own. Her "retranslation" disguising them includes the work of "Artists" in the preparation 
laboratory, and "aides naturalistes" such as Achilles Valenciennes (1794-1865). He was engaged by Cuvier in 1820 for his Ornithology project in the preparation of bird specimens, often feather by feather as stipulated in Dufresne's "Taxidermie" (567). Precisely as her 1843 advertisement above endorses, Sarah was indeed "consult[ing] those most skilled in the Art," verified by practical "instructions in the laboratories of the Museum in Paris." Visibly demonstrated too is her expert reading and practical knowledge through her copies in Taxidermy of drawings from "the best writings on the subject," including Nicolas (quoted by Dufresne).

But the overt use of "I" and "me" in this footnote clearly stretches both the alleged anonymity of Taxidermy, and the deployment by women translators of additional notes (in the third person) as appropriately confined vehicles for their independent authorship by stealth. The anonymous "I" (and as Sarah Bowdich) everywhere extends "the authority of a mediator, anchored in the quintessential domestic drama of the contact zone," to quote Mary Louise Pratt and the term she famously qualifies as "the space of colonial encounters, the space in which peoples geographically and historically separated come into contact with another, and establish ongoing relations, usually involving conditions of coercion, radical inequality and untractible conflict" (Pratt 6). More to Sarah's point (with the ends initally bent down to avoid pricking of the fingers) are women's independent and overt interjections into the narratives of science through use, as here, of the more radical first-person footnote zone. As indeed a "space of colonial encounters," but outside the "domestic drama of the contact zone," Sarah Bowdich enlarges the place, and space, for the active and visible (female) participant-observer in onward tranmissions of expert knowledge. For Taxidermy the "beyond" in these notes is both physical - "in hot climates"; outside the Museum preparation laboratory - and textual. Sarah Bowdich's footnote zone therefore marks out the new space for transmission and translation of Dufresne improved "instructions" deriving from others' expert practices. This call to and inclusion of significant others (by inference, herself) importantly prefaces the second, "non-Dufresne," half of Taxidermy that has entirely escaped critical notice:

\section{ADDITIONAL INSTRUCTIONS FOR TRAVELLERS}

The preceding treatise having been written for the use of collectors, superintendents of museums, and artists, as well as travellers, I add the Instructions drawn up by the Professors of the Jardin du Roi, at Paris, expressly for the use of the latter, to whom they are gratuitously presented. I would request this class of readers, to comprehend such parts of the previous treatise of $M$. Dufresne, as are given under the following titles.

1st, The manner of collecting and preparing objects of natural history.

2dly, The method of packing and enabling them to arrive at their place of destination in the best state possible.

$3 \mathrm{dly}$, The nature of notes which ought to accompany these objects.

4thly, An indication of the objects which are most particularly desired.

(119-20, emphasis added)

The main second part of Taxidermy addresses the categories and specific "objects" that are sought, and the persons addressed directly as finders of them, including "natives" (121), "Surgeons, and lovers of natural history [...] in their voyages" (129) and the more generic, but often ambiguously useful "traveller" (143, 160-61). For comparative history of French and international science at this pivotal moment of its development, the rich information in this second half of Taxidermy is of immense 
interest. For example, it gauges the state of health and breadth (or otherwise) of the collections at the Paris Museum and its new menagerie, especially when compared to the London Museum collections its curator, William Bullock, wished to augment through his "treatise" aimed at

sportsmen, gentlemen in the army and navy and persons going abroad [...]. By observing the following instructions, and a little practice, gentlemen will be able to give to their servants, or the natives of the country they may visit, such directions as may be the means of procuring many new and valuable objects of zoology [...]. (Bullock iii-iv, "objects of zoology" are unspecified)

But Sarah's intruding authorial perspectives and observations above - as a non-French outsider, woman, student, but also insider educator through preparing this work for Anglophone experts - make her no footnote in this transmission history. Rather, her dual-facing endeavour for "Museums and Travellers" provides in its vital copula the bi-directional retranslation of the footnote zones of taxidermy's various engagements with scientific, technical and geographical genres, while authoritatively imparting something new to them all, as we will discover.

The titles in chronological order of the main English, and French, ${ }^{2}$ precursors to Sarah's Taxidermy already indicate their target "knowledge markets" as signalled in bold:

Lettsom, John Coakley. The Naturalist's and Traveller's Companion. Containing Instructions for Collecting and Preserving Objects of Natural History and for Promoting Inquiries after Human Knowledge in General. 2nd ed. 1774.

Manesse, l'Abbé. Traité sur la manière d'empailler et de conserver les animaux, les pelleteries et les laines. 1787.

Nicolas, P. F. Méthode de préparer et conserver les animaux de toutes les classes pour les cabinets d'histoire naturelle. 1801.

Mouton-Fontenille de la Clotte, Jacques-Marie-Philippe. L'Art d'empailler les oiseaux (contenant des Principes de théorie nouveaux et les Procédés de pratiques avantageux pour conserver à chaque Famille ses formes et ses attitudes naturelles), faisant suite au Traité élémentaire d'ornithologie. 1811.

Bullock, William. A Concise and Easy Method of Preserving Subjects of Natural History intended for the use of Sportsmen, Travellers \& c., \&c. 1817.

Dufresne, Louis. "Taxidermie." Nouveau Dictionnaire d'Histoire Naturelle appliquée aux arts, à l'agriculture, à l'économie rurale et domestique, à la médecine. 1816-19.

With the exception of Lettsom, this list in effect documents an important new lineage of museum conservators who had established large personal collections: Manesse, Nicolas, Mouton-Fontenille de la Clotte, Bullock, and of course Dufresne. Clearly Brown's The Taxidermist's Manual sought aspirational status in this regard, by highlighting the (new) person of the taxidermist (and as distinct from the "stuffer," "embalmer," or more generic museum "préparateur") above the art, science, technique, method and knowledge of collecting, preserving, and conserving (taxidermy).

The second half of Taxidermy, with its restoration of the genre of "Instructions to Travellers" sets it in a lineage from at least the sixteenth century (see: Schultz). Retrospectively, it differentiates Lettsom's work as the more significant precursor than Dufresne in this list, especially upon closer intertextual inspection of the footnote zones 
of the other museum conservator texts (in English and French) set out here. For Lettsom (a Quaker, Abolitionist, Philanthropist and Traveller), the call to travel and study of nature was to enlarge understanding - of the Creator, of the universe, and of greater opportunities for human good through knowledge of plants and animals. Indeed before 1815 "instructions" often promoted philanthropic ends (see: Kury). In his introduction Lettsom claimed his Instructions to be new, although indebted to directions penned in 1771 by his (Calvinist) friend, John Reinhold Forster (1729-98) "for collecting, preserving, and transporting all kinds of natural history curiosities" (The Naturalist's and Traveller's Companion xi). Forster, however, joins a much longer lineage of important explorer-travellers such as Richard Hakluyt (1553-1616), actively engaged in natural scientific pursuits that informed their published travel advice and instructions (as Carey elucidates). Only Nicolas in the list above concertedly and overtly quotes Lettsom's work - in French translation as le Voyageur naturaliste - first as an important commentator on Turgot's "Instructive Dissertation on how to collect, prepare, conserve and transport every kind of natural history curiosity" [Mémoire instructif sur la manière de rassembler, de préparer, de conserver et d'envoyer les diverses curiosités d'histoire naturelle] (also a source for Dufresne), and then as an authority for the methods of preserving birds, insects, and fish (Nicolas, Méthode: 19, 84-86, 166-67 and 188-89 respectively). Sarah cannot have missed Lettsom when consulting Nicolas's work to make copies for her Taxidermy of two of the plates describing the preparation of birds. Her notice above to the translation in the second half of Taxidermy of the latest Instructions, drawn up by (unsigned) "Professors" of the Paris Museum, therefore draws direct attention to fascinating role switches, even usurpations, by these new instructors. Their positions were formerly commanded by pre-eminent "voyageurs naturalistes" (like Forster and Lettsom), and eminent contemporaries such as Alexander von Humboldt because they were the principal authorities on collecting, preparing, and packing ("conserver et envoyer") diverse objects of natural history in situ.

There is no mistaking the many jostling and competing echelons of instructors within, and beyond, the Museum here: Professors, chief "aides naturalistes" and other "préparateurs," expert scientific travellers. But their ambiguous hierarchies are further compounded by the strategic authorial intrusions within this notice: "I add the Instructions drawn up by the Professors of the Jardin du Roi, at Paris, expressly for the use of the latter" (Taxidermy 119, emphasis added). These travellers are, however, no secondary category, but appositional to "collectors, superintendents of museums, and artists." So the complex tensions of function, role, contribution and authority among the instructors equally apply to the instructed within, and beyond, the Museum's departments. In a literally pivotal authorial intervention, the anonymous "I" of Taxidermy translates - that is collects, preserves and mounts - a major juncture in the redrawing of field and laboratory natural science in 1820, and as demonstrably more complex than the oppositional model proposed in histories of geography (see: Driver, Geography Militant) or science (Mackenzie) of the nineteenth century. "Preparers" of all stripes, as Hangay and Dingley underscore in Anglophone heritages, make all the difference to the successes of collections for both museum and field trajectories of expertise.

When the "I" here is named, embodied and contextualised, however, these striking first person interventions provide a particular ideological steer amid these shifting categories: "[...] expressly for the use of the latter [travellers]. I would request this class of readers to comprehend [...] the previous treatise of M. Dufresne" (119, emphasis added). Taxidermy is not targetted to informed generic or leisured travellers, but specifically designed for "voyageurs naturalistes" in the French sense and heritage 
of Lettsom's and Nicolas's usage. Moreover, this important distinction differentiates the scientific traveller from the figure of the discoverer, explorer or adventurer such as a Baudin or a Cook. Knowledge enrichment, not land or imperial conquest, is the primary object of endeavour. The model "voyageur naturaliste" for whom Taxidermy is written turns out to be its author (and her husband), mapping onto their immediate personal, but also French institutional, contexts in 1819-20. The Bowdichs represent non-French prototypes for the specially-trained professional French "voyageurs naturalistes," on the payroll of the Paris Museum for the first time (Laissus 262-63), so that they could undertake specialist specimen gathering to augment Gallery and living collections. Cuvier's stepson, Alfred Duvaucel (1793-1824), was also among their number collecting new species for the Museum in Asia and India. In the Instructions half of Taxidermy it is particularly striking that species specified for collection are mainly from West Africa, the Cape of Good Hope, Madagascar, India and the Indian Archepelago. In subsequent editions of Taxidermy these sections are the most regularly updated and augmented. Only in the fourth edition (1835) are new sections added, for Chile, Peru and Brazil.

The Instructions half of Taxidermy is where Sarah's authorial mark is more complex, in part because her intimation of its intertext - the rather vague "drawn up by the Professors of the Jardin du Roi" - fits a developing model since the 1750s. The opening paragraph however provides contextual and intertextual clues to enable its discovery by equivalence with Dufresne (the latest published expert instructions for voyageurs naturalistes):

\section{ANIMAL KINGDOM}

The study of zoology in the Museum of Natural History, does not limit itself to the observation of the forms of animals and the description of their organs; it also embraces the examination of their habit, their development, their sagacity; and seeks if they can be of any utility. Formerly, we could only inform ourselves on these essential points by the relations of travellers. [...] But, since a menagerie has been added to the Museum at Paris, a new career in observations had been opened to naturalists. (Taxidermy 120, emphasis added)

The source - the œuvre; the word-for-word original for this paragraph - is L'Instruction pour les voyageurs et pour les employés dans les colonies sur la manère de recueillir, de conserver et d'envoyer les objets d'histoire naturelle, rédigée sur l'invitation de S. E. le ministre de la Marine et des Colonies par l'administration du Muséum royal d'histoire naturelle of $1818 .^{3}$ Sarah, however, suppresses some 30 intial pages, her translation here picking up the original precisely, from the second chapter entitled "Zoology," and from its second section headed "mammals and birds" [mammifères et oiseaux]. But her authorial intervention is then the more apparent in her different word choice to translate what has now become the main heading for the Instructions half of Taxidermy: "Animal Kingdom." This direct reference to (George) Cuvier's Règne Animal (1817) is also acknowledgement by inference to the work of his younger brother Frédéric (1773-1838), first keeper of the new Paris menagerie (1804-38), flagged in the emphasis above. Only tiny suppressions (and changes of paragraphing) follow, before more radical reorganisation occurs some ten pages into the "translation." Short paragraphs - on collecting fish; terrestrial and aquatic shells; worms - are lifted from sections two and three in the original second chapter - to preface substantial material drawn from its first section. This covers the preparation and packing of specimens in 
the field (recovering ground familiarly like Dufresne and quoting him as fuller reference). Sarah's overall compression of some forty pages of the original into twenty pages completes the main overview part of her English Instructions. Her freest recomposition of the French Instruction is her reorganisation of its lists of species desiderata region by region. Instead of mirroring the original's separate lists mammals and birds, then invertebrates and so on - the remainder of the second part of Taxidermy groups together requested fauna by regional destination of collection, not by separate classes of organism.

In her re-authoring here Sarah clearly envisages the collection priorities of the expert "voyageur naturaliste," not the Museum "aide naturaliste." But her greatest compositional reconfiguration of the original then becomes the more striking. The English text entirely omits the first chapter of the French Instruction as rationale for its whole: "ANTHROPOLOGY OR NATURAL HISTORY OF MAN" [ANTHROPOLOGIE OU HISTOIRE NATURELLE DE L'HOMME]. Anglophone scientific travellers therefore have no instructions for collecting the heads or other preserved bodyparts of humans from other climes. By concerted authorial interventions in both its halves, Taxidermy therefore overtly distinguishes non-human specimen collecting, preserving and mounting from the extensive human collection endeavours at the Paris Museum (and later Musée de l'Homme). Display among others of the "Hottentot Venus," whom (G.) Cuvier dissected, is perhaps its best-known specimen of notoriety.

Sarah Bowdich's dual-facing Taxidermy to both Museums and (scientific) Travellers is therefore quite unlike Brown's seemingly similar Taxidermist's Manual. In its scope and target readership, in its translation and re-composition procedures (and acknowledgements) and its first-person commentary it presents the most current international (French) natural science practices in knowledge gathering, preserving and mounting. Sarah's compact and composite retransmission of Dufresne's second revised edition of "Taxidermie," because integral to the Museum cursus of the 1818 Instruction, therefore makes Taxidermy a double first among Anglophone works targeting specialist scientific traveller collectors, as well as future "career naturalists" in menageries (modelled on the Paris collections). Additionally, it is a double first for a woman author, regarding the genres of both the modern scientific taxidermy manual, and instructions for scientific travellers, or their compilation. By offering vital information on the practicalities of how to undertake species collection now identified additionally by comparative geographical zone, Taxidermy extends information not always found separately in geographies, scientific treatises, travel guides, naturalists' companions (à la Lettsom), or in specialist instruction lists of desirable exotica unsupported by necessary directions (manuals) for their successful practical collection. An example of the latter is Chevalier Soulange-Bodin's Instruction adressée aux NaturalistesVoyageurs (1826) for the Jardin de Fromont. Moreover, because neither a "faithful" (cover-to-cover) translation, nor an illustrated natural history compendium, Taxidermy also sets itself apart in terms of its form within the corpus of the Bowdichs' other translation-transmission publications (see: Appendix 1).

Taxidermy is therefore much more than a derivative copy, transcription, translation (in the narrow sense), adaptation or imitation - of the manual (à la Brown), the travel guide (à la Mollien) or Instructions (for "voyageurs naturalistes"). In consequence its primary hybridity poses fascinating questions for historians of science and experts in translation and comparative literary-cultural studies regarding its contributions to knowledge, generic (re)classification and precedence. Evaluation of Taxidermy as a major contribution to early nineteenth-century natural science thus 
ultimately hangs on the status accorded to its authoritative insider first-person perspectives and double expert audiences, which are everywhere comparative.

Taxidermy clearly magnifies the already composite genres of the modern scientific treatise, first by further blending them, and second by the use of informed authorial comments overtly flagged in the text. These expand and correct a key earlier authority, itself built upon established information with inter-lingual and intra-lingual provenance. An example of the latter is Dufresne's lengthy description of how to make enamel eyes for bird collection, concluding his "Taxidermie" (1816-19), as an acknowledged insertion, copied directly from Manesse (1787). The question behind Taxidermy, namely how (better) to collect and preserve, is thus determined by demonstrable additional first-hand expertise tested against (the best) known authorities. But furthering best international practice in "collecting, preparing and mounting objects of natural history" is only one of Taxidermy's objectives. It also highlights how the best practitioner-experts in a field and its techniques do not work in isolation. Taxidermy's constituent instructors and informants of its author - Dufresne for taxidermy, Cuvier (G. and F.) among other Professors expanding Museum knowledge of living, and fossil, specimen collections - each relied on comparative anatomy for better identification, classification and verification of forms, enhanced by the menagerie. Taxidermy importantly targets better live comparative collecting in the field, because this activity is now informed by how the specimen will later be investigated in laboratories of comparative anatomy (dissection) and conservation (taxidermy). Taxidermy's focus on preparing objects of natural history is therefore equally about better preparing scientific preparers for work outside the Museum, because this is central to work inside it. Although no Professor, the "I" of Taxidermy can authoritatively instruct and enhance future overseas scientific collecting, thanks to having already experienced its many practical difficulties in hot climates (with T. Edward Bowdich in Ashanti), and through participant observation and instruction in the relevant Paris Museum departments.

The subject of Taxidermy's vital copula - revealing it as authored, and not merely a translated work - primarily promotes an expert participant-observer view of the many competing echelons and cross-over positions of instructors and the instructed within and beyond the Paris Museum. From the standpoints of its double intertextual provenance, and re-editions, Taxidermy's ideological, structural and formal/generic steer on behalf of scientific field collection can now be further clarified as potentially foundational. The two re-editions before the Bowdichs' departure for Sierra Leone are little different from the first; the three thereafter are more significant in displaying the work of (anonymous) women in science. As a clearly-conceived, single-volume, practical scientific instruction work combining the best expertise of two subgenres Taxidermy from 1820 upholds particular agendas for understanding the taxa of "skins" in scientific endeavour, and marks itself out in consequence from its generic lineages and counterparts. First is its overt exclusion of instructions for the collection and preparation of human subjects and body-parts, counterbalanced by its ethics of inclusion. All non-human forms are equally collectable and valuable for science, especially from least-known regions. Second, Taxidermy concentrates with first-hand insight on preparing key scientific preparers who will remain largely outside the aegis and payroll of national Museums but in their work are nevertheless vital partners overseas and "at home." Third, Taxidermy retranslates the 1818 French Instruction as model textbook manual designed to promulgate particular responsibility for colonial expansion in the training of future institutional "aides naturalistes" and "voyageurs naturalistes." The Bowdichs were invited to serve the French Government in 1820-21, but declined. Their beliefs, like Lettsom's, were that scientific endeavour had no 
nationality or national interest, because for the more general good of mankind. Sarah's Taxidermy is, then, a best-practice scientific "conduct book" for particular use by informed protagonists in the advancement of science. If the conduct book more than other genres has been gendered female in its readerships and authors, my argument for labelling Taxidermy as a scientific conduct book responds directly to Ann B. Shteir's call for researchers to engage with "canonical and non-canonical forms" of women's writing of science (317). With hindsight, Taxidermy's multiple agendas for the extension of science could not have been more imperative. Even as the Bowdichs left for Sierra Leone in 1822, the Paris Museum training programme for their paid cadre of "voyageurs naturalistes" had essentially folded. The greater success of Taxidermy - in effect a major reason to explain its immediate and frequent plagiarism in the Anglosphere - was its potentially better preparation of non-institutional experts for national, as well as international, natural history collecting, because it instructed new collectors by means of the standards set in 1818-19 by "Professors" at the Paris Museum.

In the next decades of the nineteenth century taxidermy moved more mainstream and front-of-house - into private settings and drawing-rooms, amateur collections, regional museums and businesses employing and run by women - leaving the work of expert dissection and exhibition to national Museum laboratories and increasingly professionalized experts. Valuing inside(r)s increasingly over outside(r)s translated by 1840 into formations and hierarchies of insiders and outsiders to serious scientific endeavour, primarily led by scientific institutions with imperialising missions, rather than by expert collectors overseas. By writing herself as model scientific collector, preparer and educator from outside into her expertly re-composed text in 1843, Sarah Bowdich ultimately demonstrates that scientific endeavour and authorship are multiple, combined, accumulative, partial and therefore open. Her call for greater inclusiveness - as opposed to segregation by primary and secondary orders of contribution and contributor (irrespective of gender) - can now be better grasped and heard behind Taxidermy's strategically chosen opening line from 1821: "Natural history can only make a rapid progress when museums are enlarged" (2nd ed., emphasis added). As a foundational "scientific conduct book" for training and preparing expert outsiders into nineteenth-century science at home, and overseas, Taxidermy therefore encourages further twenty-first-century critical attention to the moral, inter-lingual and educative dimensions of scientific and travel writing, and scientific translation of this period for science, since it also prepared our own.

The original anonymity of Taxidermy - whether a deliberate strategy or not unquestionably served "I" well, since the authority of Taxidermy in all its editions (including of 1843) was, as demonstrated above, the chief reason for its reprints. For history and sociology of science, merely to add forgotten or anonymous (female) authors to rosters of women in science leaves largely unchallenged the prevailing, and often gendered, hierarchies of primary and secondary contributions/contributors to science fields in all periods. Sarah's "advertisement" neatly articulates the problem: "as if an anonymous author were a fairer object for piracy than one whose name stands on the title page" (Lee iv). Our application of the insights of comparative literary, travel and translation studies to analysis of the merits of Taxidermy within the history of its science not only challenges science "translation" as a derivative, secondary production, it also demonstrates the innately inter- and intra-lingual nature of expert science writing and its transmissions, if these are to enlarge their fields. That Taxidermy was written by a woman as "fairer object" is therefore of quintessential interest to how its transmissions of science - as multiple knowledge transfer, as co-authoring practice, as translation of 
objects as well as ideas - redefined primary players, functions and facilitations in science work outside binary, national or disciplinary oppositions. By the same token, travel and translation studies, including those foregrounding gender, can no longer ignore the genres of the sciences as largely minority interests (as recent overview studies such as Pym; Sapiro; and McLaughlin suggest). It is therefore not so much the translator's "invisibility" (see: Venuti) or her sex (see: Delisle; Delisle and Woodsworth) that are at stake in Taxidermy, but the subject of taxidermy itself as model for the arts and sciences of re-articulating living and dead knowledge.

A history of European taxidermy has yet to be written, as too a history of women in (national, European, international) taxidermy. The primary importance of Taxidermy (1820-43) for such ventures has been demonstrated above as covering very much more than the place of its author - as the first woman in English, and in other European languages to pen such a work. Taxidermy demonstrates that this subject is a vital international contact zone, including for women's scientific work, and outside the containments of Pratt's "quintessential domestic drama" (6). By mounting her own authorial "skin" by means of careful preparation of its earlier life forms - texts, objects, practices, instructors, other tongues - Sarah Bowdich in her evolving Taxidermy demonstrates that enrichment, reconfiguration and enlargement of science endeavour and authorship is without gender, class, race or exception. Her work (physical, textual, intellectual) now requires a much more prominent place in the galleries of history of science and literature showcasing scientific and cultural "préparateurs," because Taxidermy instructs us how better to comprehend multi-mediated re-transmissions of intercultural scientific knowledge and understanding. 
Appendix 1: Works by "Thomas Edward Bowdich" produced during the Bowdichs' sojourn in Paris, 1819-22

1820:

Travels in the Interior of Africa to the Sources of the Senegal and Gambia; performed by Command of the French Government in the Year 1818 by G. Mollien. London: Henry Colburn and Co.

Taxidermy: on the Art of Collecting, Preparing and Mounting Objects of Natural History. For the Use of Museums and Travellers. London: Longman, Hurst, Rees, Orme and Brown.

1821:

The British and French Expeditions to Teembo, with Remarks on Civilization in Africa. Paris: J. Smith.

An Essay on the Superstitions, Customs and Arts common to the Ancient Egyptians, Abyssinians and Ashantees. Paris: J. Smith.

An Analysis of the Natural Classifications of Mammalia. For the Use of Students and Travellers. Paris: J. Smith.

An Introduction to the Ornithology of Cuvier. For the Use of Students and Travellers. Paris: J. Smith.

Taxidermy: on the Art of Collecting, Preparing and Mounting Objects of Natural History. For the Use of Museums and Travellers. 2nd Revised Edition. London: Longman, Hurst, Rees, Orme and Brown.

1822:

Elements of Conchology, including the Fossil Genera and the Animals. Part 1: Univalves with upwards of 500 Figures. Paris: J. Smith; London: Treuttel and Würtz.

Elements of Conchology, including the Fossil Genera and the Animals. Part II: Bivalves. Multivalves. Tubicolae. Paris: J. Smith; London: G. B. Sowerby and H. S. Tutchbury.

1823:

A Geognostical Essay on the Superposition of Rocks in both Hemispheres by Alexander von Humboldt. Translated from the original French. London:

Longman, Hurst, Rees, Orme, Brown \& Green.

History and Description of the Royal Museum of Natural History. Translated from the French of M. Deleuze. Paris: L.T. Celliot.

Taxidermy: on the Art of Collecting, Preparing and Mounting Objects of Natural History. For the Use of Museums and Travellers. 3rd Revised Edition. London: Longman, Hurst, Rees, Orme and Brown.

1824:

An Essay on the Geography of North-Western Africa. Paris: L.T. Cellot, 1824.

An Account of the Discoveries of the Portuguese in the Interior of Angola and Mozambique from Original Manuscripts. To which is added a note by the Author on a Geographical Error of Mungo Park in his last Journal into the Interior of Africa. London: John Booth. 


\section{Notes}

1. For indicative further reading about these forgotten pioneer naturalists, see Langard (2007) on Nicolas; Péquignot (2006) on Mouton-Fontenille; Sweet (1970a) on Bullock and (1970b) on Dufresne, and Coleman (2006) on Lettsom. Manesse has received negligible attention, and is not the first writer of a taxidermy manual, as the unidentified author of the online "El Abad Manesse" claims.

2. The English translation of the French titles in this list is:

Manesse, l'Abbé. Treaty on the manner of stuffing and conserving animals, skins and fur (1787); Nicolas, P. F. Method in preparing and conserving animals in all classes for cabinets of natural history (1801); Mouton-Fontenille de la Clotte, Jacques-MariePhilippe. The Art of Stuffing birds (containing the new Principles of theory and Procedures for advantageous practices for the conservation of each Family, its forms and natural attitudes), being the supplement to the Elementary Treaty of ornithology (1811); Dufresne, Louis. "Taxidermy." New Dictionary of Natural History applied to the arts, to agriculture, to rural and domestic economy, and to medicine (1816-19).

3. The English translation is Instruction for travellers and employees in the colonies on how to collect, conserve and transport objects of natural history, edited by the adminstration of the Royal Museum of Natural History by invitation of the Ministry of the Marine and for the Colonies. For a brief synopsis, and account of its many reprints, see Kury (85-87). 


\section{Works Cited}

Anon. Taxidermy: or the Art of Collecting, Preparing and Mounting Objects of Natural History. For the Use of Museums and Travellers. London: Longman, Brown, Green and Longmans, 1820.

---. Taxidermy: or the Art of Collecting, Preparing and Mounting Objects of Natural History. For the Use of Museums and Travellers. 2nd ed. London: Longman, et al., 1821.

---. Taxidermy: or the Art of Collecting, Preparing and Mounting Objects of Natural History. For the Use of Museums and Travellers. 3rd ed. London: Longman, et al., 1823.

---. Taxidermy: or the Art of Collecting, Preparing and Mounting Objects of Natural History. For the Use of Museums and Travellers. 5th ed. London: Longman, et al., 1835.

Abir-Am Pnina G. and Dorinda Outram, eds. Uneasy Careers and Intimate Lives: Women in Science 1789-1979. New Brunswick and London: Rutgers UP, 1989.

Bassnett, Susan. "Travel Writing and Gender." The Cambridge Companion to Travel Writing. Eds. Peter Hulme and Tim Youngs. Cambridge: Cambridge UP, 2002. 225-41.

Beaver, Donald deB. "Writing Natural History for Survival - 1820-1856: the Case of Sarah Bowdich, later Sarah Lee." Archives of Natural History 26.1 (1999): 1933.

---. "Mrs R. Lee.” Oxford Dictionary of National Biography online (2007).Web. 27 August 2014.

Blanckaert, Claude, et al. Le Muséum au premier siècle de son histoire. Paris: Éditions du Muséum National d'Histoire Naturelle, 1997.

Bret, Patrice, ed. L'Expédition d'Egypte: une entreprise des Lumières, 1798-1801. Paris: Editions Techniques et Documentation, 1999.

Brisset, Annie. "Clémence Royer, ou Darwin en colère." Portraits de Traductrices. Ed. Jean Delisle. Ottowa: Presses de 1'Université d'Ottawa, 2002. 173-203.

Bullock, William. A Concise and Easy Method of Preserving Subjects of Natural History intended for the use of Sportsmen, Travellers \&c., \&c. London: printed for the proprietor, 1817.

Burek, Cynthia V. and Bettie Higgs, eds. The Role of Women in the History of Geology. London: Geological Society Special Publications 281, 2007.

Carey, Daniel. "Hakluyt's Instructions: The Principal Navigations and SixteenthCentury Travel Advice." Studies in Travel Writing 13:2 (2009): 167-85.

Coleman, Deirdre. "Entertaining Entomology: Insects and Insect Performers in the Eighteenth Century." Eighteenth-Century Life 30:3 (Fall, 2006): 107-34.

Connor, Steven. "The Right Stuff." Modern Painters (March, 2009): 58-63.

Coote, Anne. "Science, Fashion, Knowledge and Imagination: Shopfront Natural History in $19^{\text {th }}$-Century Sydney." Sydney Journal 4:1 (2013): 1-18.

Delisle, Jean, ed. Portraits de Traductrices. Ottawa: Presses de l'Université d'Ottawa, 2002.

Delisle, Jean and Judith W. Woodsworth, eds. Translators through History. Amsterdam and Philadelphia: John Benjamins, 2012.

Driver, Felix. Geography Militant: Cultures of Exploration and Empire. Oxford: Blackwell, 2001.

---. "Bowdich, Thomas Edward." Oxford Dictionary of National Biography online (2011). Web. 28 August 2014. 
Dufresne, Louis. "Taxidermie." Nouveau Dictionnaire d'Histoire Naturelle appliquée aux arts, à l'agriculture, à l'économie rurale et domestique, à la médecine. T. 32. Paris: Déterville, 1816-19. 522-92.

Easley, Alexis. First-Person Anonymous: Women Writers and Victorian Print Media, 1830-1870. Aldershot: Ashgate, 2004.

"El Abad Manesse." Web. 29 August 2014.

Fraisse, Geneviève. Clémence Royer: philosophe et femme de sciences. Paris: La Découverte, 1985.

Gates, Barbara T., ed. In Nature's Name: An Anthology of Women's Writing and Illustration, 1780-1930. Chicago: Chicago UP, 2002.

Hangay, George and Michael Dingley. Biological Museum Methods. Vol. 1: Vertebrates; Vol. 2: Plants, Invertebrates and Techniques. Sydney, Orlando, San Diego, NY, London, Toronto, Montreal, Tokyo: The Australian Museum, Sydney, Australia, Academic Press, 1985.

Harvey, Joy. "Almost a Man of Genius": Clémence Royer, Feminism and NineteenthCentury Science. New Brunswick: Rutgers UP, 1999.

Kohlstedt, Sally Gregory and Donald L Opitz. "Re-imag(in)ing Women in Science: Projecting Identity and Negotiating Gender in Science." The Changing Image of the Sciences. Ed. Ida H. Stamhuis, et al. Dordrecht, Boston, London: Kluwer Academic Publishers, 2002. 105-39.

Kury, Lorelai. "Les Instructions de voyage dans les expéditions scientifiques Françaises (1750-1830)/Travel instructions for the French scientific expeditions (1750-1830)." Revue d'histoire des sciences 51.1 (1998): 65-92.

Laissus, Yves. "Les Voyageurs naturalistes du Jardin du roi et du Muséum d'histoire naturelle: essai de portrait-robot." Revue d'histoire des sciences 34.3-4 (1981): 259-317.

Langard, Delphine. 'Pierre-François Nicolas, un 'monument' de la chimie par son enseignement et ses œuvres au XVIII siècle." Thèse doctorale: Université Henri-Poincaré Nancy I, 2007.

Lee, Mrs R. "Advertisement." Taxidermy: or the Art of Collecting, Preparing and Mounting Objects of Natural History. For the Use of Museums and Travellers. 6th ed. London: Longman, Brown, Green and Longmans, 1843). iii-iv.

Lettsom, John Coakley. The Naturalist's and Traveller's Companion. Containing Instructions for Collecting and Preserving Objects of Natural History and for Promoting Inquiries after Human Knowledge in General. 2nd ed. 1774.

L'Instruction pour les voyageurs et pour les employés dans les colonies sur la manère de recueillir, de conserver et d'envoyer les objets d'histoire naturelle, rédigée sur l'invitation de S. E. le ministre de la Marine et des Colonies par l'administration du Muséum royal d'histoire naturelle. Paris: A. Belin, 1818.

Livingstone, David N. and Charles W. J. Withers, eds. Geographies of NineteenthCentury Science. Chicago: U of Chicago P, 2011.

McEwan, Cheryl. Gender, Geography and Empire: Victorian Women Travellers in West Africa. Aldershot and Burlington: Ashgate, 2000.

MacKenzie, John M., ed. Imperialism and the Natural World. Manchester: Manchester UP, 1990.

McLaughlin, Mairi. "Translation Studies.” French Studies 68.3 (July 2014): 377-85.

Marcinkus, Andrea Kolanski. "Nature Fancywork: Nineteenth-Century Women Tell Stories about the Natural World." Textile Society of America Symposium Proceedings (2006): 245-25. 
Martin, Alison E. "Revolutions in Botany: Nation, Gender and Education in the French Translation of Priscilla Wakefield's Introduction to Botany (1796)." Journal of Literature and Science 4.1 (2011): 30-43.

---. "Performing Scientific Knowledge Transfer: Anne Plumptre and the Translation of Martin Heinrich Lichtenstein's Reisen im südlichen Afrika (1811)." Journal of Literature and Science 8.1 (2015): 9-26.

Martin, Alison E. and Susan Pickford, eds. Travel Narratives in Translation, 17501830: Nationalism, Ideology, Gender. London and New York: Routledge, 2012.

Miles, Sara Joan. "Clémence Royer et de l'Origine des Espèces: traductrice ou traîtresse?" Revue de Synthèse 4 (1989): 61-83.

Mills, Sara. The Discourses of Difference: An Analysis of Women's Travel Writing and Colonialism. London: Routledge, 1993.

Morris, Pat. A History of Taxidermy: Art, Science and Bad Taste. Ascot: MPM Publishing, 2010.

Nicolas, P. F. Méthode de préparer et conserver les animaux de toutes les classes pour les cabinets d'histoire naturelle. Paris : chez F. Buisson, 1801.

Orr, Mary. Intertextuality: Debates and Contexts. Cambridge: Polity Press, 2003.

---. "Pursuing Proper Protocol: Sarah Bowdich's Purview of the Sciences of Exploration." Victorian Studies 49.2 (Winter 2007): 277-85.

---. "Fish with a Different Angle: The Fresh-Water Fishes of Great Britain (18281838) by Mrs Sarah Bowdich.” Annals of Science 71.2 (2014): 206-40.

---. "Women Peers in the Scientific Realm: Sarah Bowdich (Lee)'s Expert Collaborations with Cuvier, 1825-1833." Notes and Records 69.1 (March, 2015): 37-51.

Péquignot, Amandine. 'Une peau entre deux feuilles, l'usage de l'herbier' en taxidermie aux XVIII ${ }^{\mathrm{e}}$ et XIX ${ }^{\mathrm{e}}$ siècles en France/ A skin between two leaves: The use of the herbarium in taxidermy during the 18th and 19th centuries in France." Revue d'histoire des sciences 59.1 (2006): 127-36.

Poovey, Mary. The Proper Lady and the Woman Writer: Ideology as Style in the Works of Mary Wollstonecraft, Mary Shelley, and Jane Austen. Chicago: Chicago UP, 1984.

Pratt, Mary Louise. Imperial Eyes: Travel Writing and Transculturation. London and New York: Routledge, 1992.

Pym, Anthony. Exploring Translation Theories. London and New York: Routledge, 2010.

Sapiro, Gisèle, ed. Traduire la littérature et les sciences humaines: conditions et Obstacles. Paris: Ministère de la Culture et de la Communication, 2012.

Schultz, Eva. "Notes on the History of Collecting and of Museums in the Light of Selected Literature of the Sixteenth to the Eighteenth Century." Journal of the History of Collections 2.2 (1990): 205-18.

Simon, Sherry. Gender in Translation: Cultural Identity and the Politics of Transmission. London and New York: Routledge, 1996.

Shteir, Ann B. "Botanical Dialogues: Maria Jacson and Women's Popular Science Writing in England." American Society for Eighteenth-Century Studies 23:3 (Spring 1990): 301-17.

Spivak, G. C. "Can the subaltern speak?" Marxism and the Interpretation of Culture. Ed. C. Nelson and L. Grossberg. Basingstoke: Macmillan, 1988. 271-313.

Sweet, Jessie M. "William Bullock's Collection and the University of Edinburgh." Annals of Science 26.1 (1970a): 23-32. 
---. "The Collection of Louis Dufresne (1752-1832)." Annals of Science 26.1 (1970b): 33-71.

Tymoczko, Maria. "Trajectories of Research in Translation Studies." Meta 50.4 (2005): 1082-97.

Venuti, Lawrence. The Translator's Invisibility: A History of Translation, 2nd ed. London and New York: Routledge, 2002.

Williams, Leslie Pearce. "Science, Education and Napoleon I." Isis 47.4 (Dec. 1956): 369-82. 